\title{
The rehabilitation in the management of Transthyretin Familial Amyloid Polyneuropathy
}

\author{
Agnès Morier ${ }^{1 *}$, Alyssa De Sousa ${ }^{2}$, Colombe Lemoine $^{1}$, Cecile Cauquil ${ }^{1}$, Marie Théaudin ${ }^{1}$, David Adams $^{1}$, \\ Hervé Chanut ${ }^{2}$
}

From First European Congress on Hereditary ATTR amyloidosis

Paris, France. 2-3 November 2015

\section{Introduction}

The rehabilitation is part of a drug free therapy management of peripheral polyneuropathy. The Transthyretin Familial Amyloid Polyneuropathy this illness entails deficiencies that do impact on the day to day physical comfort and everyday life of patients. They have motor function and sensory consequences.

\section{Methods}

To be able to offer a well-adapted rehabilitation program, the rehabilitation therapists have put into place assessments in order to estimate the different clinical manifestations described by the patients. The pain, the paresthesia and strength deficiency will be evaluated in this way, and their evolution followed up, thanks to comparative test. We have been looking for tools to be able to evaluate the clinical manifestations and their evolution.

\section{Results}

For that purpose, we have chosen comparative tests that allow to measure quantitative and qualitative results. The pain and the tiredness are evaluated with visual analogue scales, the strength with muscular testing and dynamometer, the functional aspect is tested with an evaluation of: the standing upright; the handicap situation and the 6 minute walking test. The assessments' have improved in recent years with more precise tools.

\section{Conclusion}

It is essential to stay as close as possible to the felt effects of the patients to deal with unbiased variations and put into place an adapted rehabilitation program.

${ }^{1}$ Centre de Références Neuropathies Rares (NNERF), service de Neurologie Adulte, Univ Paris Sud, CHU Bicêtre, 78 rue du Général Leclerc 94275 Le Kremlin Bicêtre, Paris, France

Full list of author information is available at the end of the article
Authors' details

${ }^{1}$ Centre de Références Neuropathies Rares (NNERF), service de Neurologie Adulte, Univ Paris Sud, CHU Bicêtre, 78 rue du Général Leclerc 94275 Le Kremlin Bicêtre, Paris, France. ${ }^{2}$ Equipe de rééducation du Centre de Références Neuropathies Rares (NNERF), CHU Bicêtre, 78 rue du Général Leclerc 94275 Le Kremlin Bicêtre, Paris, France.

Published: 2 November 2015

doi:10.1186/1750-1172-10-S1-P66

Cite this article as: Morier et al:: The rehabilitation in the management of Transthyretin Familial Amyloid Polyneuropathy. Orphanet Journal of Rare Diseases 2015 10(Suppl 1):P66.
Submit your next manuscript to BioMed Central and take full advantage of:

- Convenient online submission

- Thorough peer review

- No space constraints or color figure charges

- Immediate publication on acceptance

- Inclusion in PubMed, CAS, Scopus and Google Scholar

- Research which is freely available for redistribution

Submit your manuscript at www.biomedcentral.com/submit
() Biomed Central
C Biomed Central

(c) 2015 Morier et al. This is an Open Access article distributed under the terms of the Creative Commons Attribution License (http:// creativecommons.org/licenses/by/4.0), which permits unrestricted use, distribution, and reproduction in any medium, provided the original work is properly cited. The Creative Commons Public Domain Dedication waiver (http://creativecommons.org/publicdomain/ zero/1.0/) applies to the data made available in this article, unless otherwise stated. 